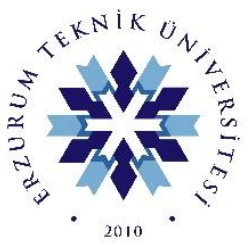

ÖĞRETMEN ADAYLARININ HOŞGÖRÜ DEĞERINE YAKLAŞIMI THE TEACHER CANDIDATES APPROACH TO THE VALUE OF TOLERANCE

\title{
CEREN UTKUGÜN
}

Dr. Öğr. Üyesi, Afyon Kocatepe Üniversitesi, Türkçe ve Sosyal Bilimler Eğitimi Bölümü cerendemirdelen@hotmail.com

(iD) https://orcid.org/0000-0002-5911-9175

SİBEL YAZICI

Dr. Öğr. Üyesi, Afyon Kocatepe Üniversitesi, Temel Eğitim Bölümü

syazici@aku.edu.tr

iD https://orcid.org/0000-0002-1238-0720

\author{
ETÜ Sosyal Bilimler Enstitüsü Dergisi |ETU Journal of Social Sciences Institute \\ S.9, Ekim | October 2019, Erzurum \\ ISSN: 2149-939X

$\begin{aligned} \text { Makale Türü | Article Types } & : \text { Araştırma Makalesi | Research Article } \\ \text { Geliş Tarihi | Received Date } & : 01.04 .2019 \\ \text { Kabul Tarihi | Accepted Date } & : 13.10 .2019 \\ \text { Sayfa | Pages } & : 17-31 \\ \text { dol } & : \text { http://dx.doi.org/10.29157/etusbe.119 }\end{aligned}$

www.etusbe.com 



\title{
ÖĞRETMEN ADAYLARININ HOŞGÖRÜ DEĞERİNE YAKLAŞIMI
}

\author{
Ceren UTKUGÜN, Sibel YAZICI
}

ETÜ Sosyal Bilimler Enstitüsü Dergisi (ETÜSBED), S.9, Ekim 2019, Sayfa: 17-31

\section{ÖZ}

Öğretmenlerin hoşgörü eğitiminde önemli bir yere sahip olduğu yapılan pek çok araştırmada ortaya konulmuştur. Bu bağlamda öğretmenler okullardaki hoşgörü ve bir arada yaşama kültürünün oluşmasındaki en temel etkenlerdendir. Bunun için öğretmen adaylarının hoşgörü değerine bireyel ve mesleki açıdan yaklaşımları ve aldıkları eğitimin değer oluşumuna katkısı çalışmada ele alınmıştır. Bunun ortaya çıkarılabilmesi için nitel araştırma desenlerinden biri olan fenomenolojiden yararlanılmıştır. Afyon Kocatepe Üniversitesi Eğitim Fakültesinin farklı bölümlerinde öğrenim gören yirmi yedi öğretmen adayından yarı yapılandırılmış görüşme formu ile veriler toplanmış, içerik analizi tekniği ile çözümlenmiştir. İçerik analiz süreci; verilerin kodlanması, kodları belirli kategoriler altında toplayan temaların bulunması, verilerin kodlara ve temalara göre düzenlenmesi ve tanımlanması ile bulguların yorumlanması aşamalarından meydana gelmektedir. Elde edilen bulgulara göre öğretmen adayları hoşgörüyü; kültürel, davranışsal ve duyuşsal bir değer olarak ifade etmişlerdir. Öğretmen adaylarına göre bir öğretmenin hem insani hem mesleki nitelik açısından hoşgörü sahibi olması gerekmektedir. Üniversite hayatının hoşgörülü olmaya katkı sağladığını belirten öğretmen adayları özelikle meslek bilgisi derslerinin buna etki ettiği görüşündedir.

Anahtar Kelimeler: Öğretmen adayı, Değer, Hoşgörü, Üniversite.

\section{THE TEACHER CANDIDATES APPROACH TO THE VALUE OF TOLERANCE}

\begin{abstract}
Teachers have an important place in education for tolerance made many studies. teachers in schools to the formation of the culture of tolerance and coexistence is one of the most important factors. Our study from this point teacher education nurturing institutions candidates to determine their views about tolerance. In order to discover this, one of the qualitative research patterns was used in Phenomenology. Afyon Kocatepe University Faculty of education, the right to Twenty-seven teacher candidates studying in different parts, semi-structured interview form with data collected, content analysis technique have been resolved. The content encoding of the data analysis process, codes under certain categories, which are the data which collects theme code and regulation according to themes and interpretation of findings with the defining phases occur. According to the findings of the teacher candidates the concept of tolerance; cultural, behavioral and affective as a value. according of teacher candidates are human and a teacher in terms of professional qualifications must be tolerant. Stating that university life contributes to being tolerant, teacher candidates believe that vocational knowledge courses have an impact on this.
\end{abstract}

Keywords: Teacher Candidates, Value, Tolerant, University. 


\section{Giriş}

Hoşgörü kendimize yakın veya uzak bulduğumuz insanların her türlü duygu, düşünce ve davranışlarını anlamak ve kabullenmek için o insanlara karşılıksız sevgi, sayg1, güven ve anlayış duyarak kurulan fonksiyonel bir iletişim sürecidir (Büyükkaragöz, 1995; 22). Hoşgörüyü en kısa şekilde tanımlamak gerekirse, savundukları görüşler ve açı̆̆a vurdukları duygular bizimkilerle çelişen kişileri "hoş görme" demektir. Farklı duygu ve düşünceleri doğal karşılamak, bu duygu ve düşünceleri özgürce dile getirme olanağı tanımak, zora ve baskıya başvurmadan farklılıkları kabul etmek ve belki de en önemlisi insanları sevmek hoşgörünün gerçekleşmesi için gerekli ön koşullardır (Kavcar, 1995: 1-2). Dahası Hoşgörü; farklı dil, cins, din, inanç ve anlayış bakımından başkalarının varlıklarından rahatsızlık duymama halidir. Hoşgörü; insan hak ve özgürlüklerinin hiç bir harici müdahaleye maruz kalınmadan, rahat bir şekilde kullanım imkanı bulması anlamına gelmektedir. Felsefî anlamda; bireyin bulunduğu çerçevenin dişında kalan fikir ve düşüncelerin varlığını kabul etmesi 'ben bilirim, benimki mutlak doğrudur' anlayışından uzak durmasıdır (Gürsoy, 1991: 18-21; Aslan, 2001: 359-360).

Tüm tanımlamalara bakıldığında hoşgörü insanda olumlu düşünce ve duygular yaratan bir kavramdır. Maslow'un kendini gerçekletiren insan özelliklerine ilişkin belirlediği niteliklerden biri; kendilerini, başkalarını ve doğayı olduğu gibi kabul ederek kuvvetli ve zayıf yönleriyle kendilerini ve başka insanların farklı duygu ve düşüncelerini hoşgörü ile karşılayıp oldukları gibi kabul etmeleridir (Bayındır ve Özel, 2008: 78). Dolayısıyla hoşgörü insan ve toplum hayatını düzenleyerek karşılıklı sevgi saygı ve huzur ortamının yaratılmasına imkan veren bir değer olarak aynı zamanda ahlaki bir durum olarak da kabul edilmektedir (Mutluer, 2015: 577).

Hoşgörü tarih boyunca farklı unsurları bünyesinde barındıran her medeniyet ve her toplum için önem arz eden bir kavram olmuştur. Bu anlamda Anadolu'nun çok kültürlü yapısı Selçuklular ve Osmanlılar döneminde izlenen akıllı ve hoşgörü sahibi siyasetle (Beçen, 2015: 5) bir medeniyet haline getirilebilmiştir. Bu durumun oluşmasında Anadolunun konumu ve farklı kültürlere ev sahipliği yapması kadar islam dininin farklılıklara saygı anlayışı ve Türklerin bu anlayışı birlikte yaşama kültürü olarak özümseyerek kabul etmesi önemli etkenlerdir. Neticede medeniyetler beşiği olan Anadolu'nun Selçuklu'dan itiberen Türk Yurdu haline getirilmesi için yapılan çalışmalarda hoşgörü iklimiyle hareket edilerek farklı olanın ötekileştirilmemesi, devletin etki sahasını genişletmesinde önemli bir faktördür.

Türklerin etki sahalarını genişletmelerinde hiç kuşkususuz hoşgörü sahibi bilim ve fikir adamlarının katkısı büyüktür. Bunun en güzel örneği Mevlana olup, insan ilişkilerinde kibir, gurur ve nefreti bir yana bırakarak, Yunus Emre'nin sözünde de yer aldığı gibi yaratılanı yaratandan ötürü hoş görmüştür. Bu bağlamda hoşgörü için insan sevgisi önemli bir esastır (Küçükbezirci, 2013: 22-23). 
Hoşgörülü bir insanın çevresindekilerle etkileşirken daha insancıl davranacağı; başkaları ile iyi ilişkiler kuracağı; böylece kendine ve dolayısıyla başkalarına iyi bir çevre yaratacağı varsayılır. Bu varsayımdan hareketle insan yetiştirme hedefindeki eğitim sisteminin iyi insanlar yetiştirmesi beklenmektedir (Başaran, 1995: 47). Bunun ortaya çıkarılması için eğitim ikliminde hoşgörünün varlığına ihtiyaç vardır. Bu durum çağdaş eğitimin amacı ile örtüşmektedir. Zira çağdaş eğitim; sevgi, saygı ve hoşgörü ortamında yetişmiş kendine ve içinde yaşadığı topluma karşı saygı duyan, sevgi dolu, hoşgörülü, özgür düşünceli kuşakları yetiştirmeyi hedeflemektedir (Gündüz, 1995: 14).

Şu bir gerçektirki hoşgörüsüzlük doğuştan ortaya çıan bir kavram değil sonradan öğrenilmiş bir davranıştır. Hoşgörünün bireye kazandırılmasında bu noktada eğitim önemli bir işleve sahiptir (Kaymakcan, 2007). Boyacı ve Ersever (2017)'nin beşinci sınıflar üzerine yaptıkları deneysel çalışma hoşgörünün eğitimle geliştirilebileceği sonucunu ortaya çıkarmaktadır.

Hoşgörü sahibi kuşakların yetişmesinde en büyük rol hiç kuşkusuz öğretmenlerindir. Öğretmenlerin hoşgörüyü anlamlandırma biçimi ve eğitim süreçlerinin değerlendirilmesi bu anlamda önemlidir. Öğretmen adaylarının eğitim aldıkları üniversitelerde farklı kültürleri görme ve tanıma imkânları, hoşgörünün oluşmasına katkı sağlayıcı bir unsurdur. Farklı kültürlerin birada yaşayabilme formülünün hoşgörüye ve "kendine yapılmasını arzu etmediğin bir şeyi başkası içinde arzu etme" ilkesine dayanması (Hemşinli, 2007: 28) üniversitelerin bu anlamda önemli bir işlev sahibi olduğunu göstermektedir.

Çalışma henüz mesleğe adım atmamış öğretmen adaylarının hoşgörüyü ne şekilde değerlendirdiklerini belirlemeyi hedeflemektedir. Bunun için öğretmen adaylarının hoşgörüyü kavramsal, mesleki ve üniversite hayatı noktasında değerlendirmeleri istenmiş bu amaçla;
a. Hoşgörü nedir?
b. Hoşgörü değerine sahip bir öğretmende hangi davranışlar bulunmalıdır?
c. Üniversite hayatının hoşgörülü olmanıza katkısı var mıdır?
Sorularına cevap aranmıştır.

\section{Yöntem}

\subsection{Araştırmanın deseni}

Çalışmada öğretmen adaylarından hoşgörüyü ve hoşgörülü öğretmeni tanımlamaları ayrıca üniversite hayatının hoşgörü değerinin kazanılmasına etkide bulunup bulunmadığını belirtmeleri istenmiştir. Bu amaçla nitel araştırma yöntemlerinden fenomenoloji kullanılmıştır. Zira fenomenolojide katılımcıların deneyimleri olgunun ifade edilmesine etki eden bir unsurdur (Husserl, 2012;14: akt; Sart, 2017; 70). Fenemonolojik araştırmalar, insan eylemlerinin göreceli olduğu ve yaşadığı bağlam tarafından koşullandırıldığı felsefi varsayımından hareket ederek 
olguların uzun süreli ve derin incelenmesini amaçlar. Bu tür araştırmalarda farkında olduğumuz ya da olmadığımız olgular ile ilgili yeni bilgiler elde edilmeye çalışılır (Gürbüz ve Şahin, 2016; 113). Çalışma bu noktadan hareketle öğretmen adaylarının mesleğe hazırlanma süreci içerisinde hoşgörüyü ne şekilde yorumladıkları ve eğtim süreçleriyle ne şekilde ilişkilendirdiklerini görmeyi amaçlamaktadır.

\subsection{Araştırmanın katılımcıları}

Çalışmanın verileri, gönüllü yöntemle eğitim fakültesi programlarına devam eden öğretmen adayları arasından toplanmış, katılımcıların evreni temsil etmesine dikkat edilmiştir. Ayrıca katılımcların seçiminde yansızlık temel kuralı dikkate alınarak öznel etki oluşması engellenmeye çalışılmıştır (Karasar, 2005; 112).

Araştırmaya toplam 27 öğretmen adayı katılmış, bunlardan; yedisi türkçe öğremenliği, yedisi fen bilgisi öğretmenliği, biri matematik öğretmenliği, dördü okul öncesi öğretmenliği, dördü sosyal bilgiler öğretmenliği, ikisi bilgisayar teknolojileri eğitimi öğretmenliği ve ikisi sınıf öğretmenliği programlarının son sınıflarında öğrenim görmektedir (Tablo 1). Öğretmen adaylarının özellikle son soruyu etkin bir şekilde cevaplandırabilmeleri için son sınıf öğrencileri örneklem grubunu oluşturmak üzere tercih edilmiştir.

Tablo 1: Çalışmanın Katılımcıları

\begin{tabular}{ccc}
\hline $\begin{array}{c}\text { Öğretmen Adayının } \\
\text { Öğrenim Gördüğü } \\
\text { Program }\end{array}$ & Öğretmen Adayının Kodu & $\begin{array}{c}\text { Öğretmen } \\
\text { Aday Sayıs1 }\end{array}$ \\
\hline Türkçe Öğretmenliği & TÖ1,TÖ2,TÖ3,TÖ4,TÖ5, TÖ6, TÖ7 & 7 \\
\hline $\begin{array}{c}\text { Fen Bilgisi } \\
\text { Öğretmenliği }\end{array}$ & $\begin{array}{c}\text { FBÖ1, FBÖ2, FBÖ3, FBÖ4, } \\
\text { FBÖ5,FBÖ6, FBÖ7 }\end{array}$ & 7 \\
\hline $\begin{array}{c}\text { Matematik } \\
\text { Öğretmenliği }\end{array}$ & MÖ1 & 1 \\
\hline $\begin{array}{c}\text { Okul Öncesi } \\
\text { Ŏğretmenliği }\end{array}$ & OÖÖ1,OÖÖ2, OÖÖ3, OÖÖ4 & 4 \\
\hline $\begin{array}{c}\text { Sosyal Bilgiler } \\
\text { Öğretmenliği }\end{array}$ & SBÖ1, SBÖ2, SBÖ3, SBÖ4 & 4 \\
\hline $\begin{array}{c}\text { Bilgisayar } \\
\text { Teknolojileri Eğitimi } \\
\text { Öğretmenliği }\end{array}$ & BÖTE1, BÖTE2 & 2 \\
\hline Sınıf Öğretmenliği & SÖ1, SÖ2 & 2 \\
\hline Toplam & & 27 \\
\hline
\end{tabular}

\subsection{Araştırma verilerinin toplanması ve analizi}

Çalışmada veriler iki uzman görüşü doğrultusunda hazırlanan yarı yapılandırılmış görüşme formu ile toplanmıştır. Uzman görüşleri doğrultusunda, 
"Hoşgörü nedir?" ifadesine "size neyi çağrıştırır?" cümlesi ilave edilerek fenomenomoloji yönteminden hareketle daha derinlemesine bilgi edinilmesine çalışılmıştır. Verilerin çözümlenmesinde içerik analizinden yaralanılmış, birbirine benzeyen veriler belirli kavramlar ve temalar çerçevesinde biraraya getirilerek ve bunun okuyucunun anlayabileceği şekilde organize edilerek yorumlanması sağlanmıştır. Bunun için tümevarımcı analiz kullanılarak kodlama yoluyla verilerin altında yatan kavramlar ve bu kavramlar arasındaki ilişkiler içerik analiziyle ortaya çıkarılmıştır (Yıldırım ve Şimşek, 2000; 162). Toplanan verilerin frekans değerleri hesaplanmış, öğretmen adaylarının bir soruya birden fazla görüş bildirmesinden dolayı tablolarda yüzdelere yer verilmemiştir.

\section{Bulgular}

Öğretmen adaylarından toplanan veriler analiz edilerek temalar oluşturulmuştur. Temalar, verilen cevaplar doğrultusunda üç kısma ayrılmıştır. Bunlardan ilki hoşgörünün tanımlanması; ikincisi hoşgörülü öğretmenin özelllikleri ve üçüncüsü ise hoşgörünün oluşmasında üniversite hayatının öğretmen adayları üzerindeki etkisidir.

\section{1. Öğretmen adaylarına göre hoşgörü değeri}

Öğretmen adayları hoşgörüyü üç tema üzerinden tanımlamıştır. Bunlar; kültürel değer anlamında hoşgörü, davranışsal değer olarak hoşgörü ve duyuşsal değer olarak hoşgörüdür.

Hoşgörü kültürel açıdan; tarihi, milli, dini ve toplumsal bir değer olarak kabul edilmektedir. Öğretmen adayları kavramı Mevlana ve Yunus Emre gibi kusur aramayan, hoşgörü sahibi tarihi kişiliklerle ifade etmektedir. SBÖ1 “Hoşgörü bence birinin bir kusurunu, hatasın hoşgörmektir. Mevlana Yunus Emre gibi üstadlarımızı çağrıştırmaktadır" derken SÖ1 de benzer bir ifadeyle kavrama vurgu yapmaktadır. TÖ1 ise hoşgörüyü milli anlamda değerlendirerek "Türk'ün ayak bastı̆̆g" yer olarak tanımlamaktadır. Hoşgörüyü dinin gereği olarak gören TÖ5 “....Dinimiz gereği de her Müslüman insanı hoşgörmek olması gereken bir davranıştır" ifadesiyle tanımlamaktadır. FBÖ3 hoşgörüyü "aile, çocuk, bebek" kavramalarıyla açılarken MÖ1, "İnsanlarla beraber yaşayabilme..." anlamında birlikteliği sağladığına dikkat çekmektedir.

Hoşgörü aynı zamanda davranışsal bir değerdir. Bu noktada saygı göstermek bir hoşgörü ifadesidir. SBÖ3 hoşgörüyü“...Kişilerin birbirini saygılı bir şekilde dinlemesi ve sayg göstermesi..." olarak davranış boyutuyla ifade ederken "...Bu dünyada kendimizden başka insanların da yaşadığını ve onlara karşı nasıl davranmamız gerektiğini anlatır" derken kavramın algılanmasının birarada yaşamayı kolaylaştıracağına dikkat çekmektedir. Öğretmen adayları en fazla farlılıklara ve fikirlere sayg1 gösterilmesi gerektiğini belirtmektedir. Bu konuda MÖ1 “insanlarla beraber yaşayabilme, onları fikirlerine saygı duyabilme..." olarak hoşgörüyü nitelendirirken, OÖÖ3 "Her insanın farklı olduğunu, farkl karaktere, özelliklere sahip 
olduğunu kabul etmek" olarak ifade etmektedir. Hoşgörünün aynı zamanda alçakgönüllük olduğunu belirten TÖ2 "Yeri ve zamanına göre insanın karşısındaki bireyi alttan alabilmesi, tevazu göstermesi, alçakgönüllülük gösterebilmesi..." olarak tanımlamaktadır.Hoşgörü aynı zamanda empatik bir değer olarak ifade edilmektedir. Bu konuda FBÖ1 "Sonucunun kötü olduğunu bildiğin bir davranışı başka birisine yapmamak" olarak hoşgörüyü değerlendirmektedir. Diğer taraftan iyimser olma, güleryüzlüolma, sakinlik hoşgörünün tanımlamasında öne çıkan davranışsal özelliklerdir.

Hoşgörünün duyuşsal bir değer olarakda tanımlandığı görülmektedir. Bu konuda FBÖ6'ya göre hoşgörü " ...mutluluk ve huzurdur".

Tablo 2: Öğretmen Adaylarına Göre Hoşgörü

\begin{tabular}{|c|c|c|}
\hline Tema & Kod & $\bar{f}$ \\
\hline $\begin{array}{l}\text { Kültürel (tarihi, milli, } \\
\text { dini, toplumsal..) bir } \\
\text { değer olarak }\end{array}$ & $\begin{array}{l}\text { Mevlana ve Yunus Emre } \\
\text { Osmanlı } \\
\text { Türkün ayak bastığı yer } \\
\text { Dinin gereği } \\
\text { Tasavvuf } \\
\text { Aile } \\
\text { Beraber yaşayabilme }\end{array}$ & $\begin{array}{l}3 \\
1 \\
1 \\
1 \\
1 \\
1 \\
1\end{array}$ \\
\hline Davranışsal değer olarak & $\begin{array}{l}\text { Saygı (farklılıklara, fikirlere saygı) } \\
\text { Empati kurmalı } \\
\text { Hoşgörmeli (Tolerans) } \\
\text { Sevgi- saygı ile yaklaşmalı } \\
\text { Anlayışlı olmalı } \\
\text { Sabırlı (tahammül etme) } \\
\text { İnsanları olduğu gibi kabul etmeli } \\
\text { İyimserlik (güzel bakmak) } \\
\text { Davranışlara olumlu yaklaşımda } \\
\text { bulunmalı } \\
\text { Güleryüzlü } \\
\text { Görmezden gelmeli } \\
\text { Sakinlik } \\
\text { Önyargısız davranmalı } \\
\text { Düşünerek davranmalı } \\
\text { Alttan almalı } \\
\text { Alçakgönüllü olmalı }\end{array}$ & $\begin{array}{l}6 \\
4 \\
4 \\
4 \\
4 \\
2 \\
2 \\
2 \\
2\end{array}$ \\
\hline & İnsanları anlama & 1 \\
\hline
\end{tabular}




\begin{tabular}{c|l|l}
\hline Duyuşsal değer olarak & Mutluluk & 1 \\
& Huzur & 1 \\
& Değer verme & 1 \\
\hline Toplam & 50 \\
\hline
\end{tabular}

\subsection{Hoşgörü sahibi bir öğretmende hangi özellikler olmalıdır?}

Öğretmen adaylarının cevaplandırdıkları bir diğer soru hoşgörü sahibi bir öğretmende hangi davranışların bulunması gerektiğidir. Öğretmen adaylarının hoşgörü sahibi bir öğretmende bulunması gereken özellikler konusunda verdikleri cevapların frekans değeri oldukça yüksektir. Verilerin analiz edilmesi sonucu hoşgörü sahibi öğretmenin davranışları hem mesleki hem insani değer boyutuyla ifade edilmiştir. Bu durumda hoşgörü sahibi bir insanın mesleki anlamda da hoşgörü sahibi olacağı dile getirilmektedir.

Öğretmen adayları mesleki anlamda hoşgörü sahibi bir öğretmenin ayrımcllık yapmaması gerektiğini belirtmektedir. TÖ3 "Öğrencilere sevecen yaklaşmalı, onları olduğu gibi kabul etmeli, ayrımcllı yapmamahdır." derken OÖÖ3 "Öğrencilere karşı anlayışlı, saygilı olmalıdır. Farklı yörelerde yetişmiş, farklı özelliklerde olan öğrencilere karşı hoşgörülü olmalıdır. Ayrım yapmamalıdır" ifadelerini kullanmaktadır. Dolayısıyla hoşgörü sahibi bir öğretmenin ayrım yapmamak kadar öğrencilerinin farklılıklarınada saygı duyması gerekmektedir. SÖ2'ye göre hoşgörü sahibi bir öğretmenin "Öğrencilerin davranışları karşısında öğrenciyi rencide etmek yerine sorunun kaynağını bulmaya çalışmalıdır. Öğrencileri arasında ayrım yapmadığı bir tutum..." sergilemesi gerekmektedir.

Hoşgörü sahibi bir öğretmen hem insani hem mesleki açıdan anlayış sahibi olmalıdır. TÖ2 öğretmenin "Anlayışl, sağduyulu, mütevazi, alçakgönüllü, cömert, güleryüzlü, samimi, yardımsever" olması gerektiğini belirtirken benzer bir şekilde TÖ4 "Sabırll, anlayışlı, empati yapabilen, saygıll." olmasına vurgu yapmaktadır. Dolayısıyla hoşgörü sahibi öğretmen nitelikli BÖTE1'e göre bir öğretmen “...öğrencisi hangi etnik kimliğe sahip olursa olsun ona ve düşüncelerine karşı her zaman için anlayışh olmalı onun görü̧slerini dinlemeli ve değerli olduğunu hissettirmelidir." derken hoşgörü sahibi öğretmenin farklıklara sayg1 ve öğrenciye değer vermesi gerektiğini belirtmektedir.

Hoşgörü sahibi bir öğretmenin öğrencisininin öğrenmesine katkı sağlaması gerektiğini belirten FBÖ2 "Öğrencilerini seven, sayan bir öğretmen olmalıdır. Çocuk bir şey anlamadıysa yöntem değiştirerek kızmadan anlatmalı" böylece konunun anlaşılmasına katkı sağlaması gerektiğini belirtmektedir.

İnsani boyutta bir öğretmenin nitelikleri; sevgi, saygı, cesaret sahibi, barışçıl sağduyulu mütevazi (tevazu, alçakgönüllü) cömert, güler yüzlü, samimi, yardımsever, sabırlı, empati yapabilen, sevecen, adil, duygulu, dürüst, çalışkanlık ... olarak belirtilmektedir. 
Tablo 3: Öğretmen Adaylarına göre Hoşgörü sahibi bir öğretmenin özellikleri

\begin{tabular}{|c|c|c|}
\hline Tema & Kod & Frekans \\
\hline $\begin{array}{l}\text { Mesleki değer } \\
\text { boyutuyla hoşgörü }\end{array}$ & $\begin{array}{l}\text { Öğrenci arasında ayrım yapmamalı } \\
\text { Öğrencileri sevip saymalı } \\
\text { Öğrencilere saygılı olmalı (farklılıklarına } \\
\text { saygı duymalı) } \\
\text { İyi davranmalı (öğretmen, öğrenci, çevre) } \\
\text { Öğrencisine anlayışlı olmalı } \\
\text { Öğrenciyi olduğu gibi kabul etmeli } \\
\text { Öğrenciyi rencide etmemeli } \\
\text { Öğrenciyle empati kurmalı (Çocuklar gibi } \\
\text { düşünebilmeli) } \\
\text { Öğrenciye destek olmalı } \\
\text { Öğrenciye yardımcı olmalı } \\
\text { Güleryüzlü olmalı } \\
\text { Gergin olmamalı } \\
\text { Öğrenciye taviz vermeli (suistimal } \\
\text { edilmemek üzere) } \\
\text { Öğrencilere değer vermeli } \\
\text { Öğrencileri eşit olarak sevmeli } \\
\text { Arkadaş gibi yaklaşmalı } \\
\text { Öğrencileri dinlemeli } \\
\text { Örnek olmalı } \\
\text { Hoşgörülü olmalı } \\
\text { Sabır göstermeli } \\
\text { Alçakgönüllü olmalı } \\
\text { Yöntem değiştirerek anlatmalı } \\
\text { Öğrenciye kendini sevdirmeli } \\
\text { Öğrenciye söz dinletmeli } \\
\text { Acıma duygusu olmalı } \\
\text { Öğrencisinin yalan söyleyip söylemediğini } \\
\text { anlamalı } \\
\text { Meslek aşkı olmalı } \\
\text { Rehber olmalı } \\
\text { Her hatada öğgrencisine ceza vermemeli }\end{array}$ & $\begin{array}{l}6 \\
3 \\
3 \\
3 \\
3 \\
2 \\
2 \\
2 \\
2 \\
1 \\
1 \\
1 \\
1 \\
1 \\
1 \\
1 \\
1 \\
1 \\
1 \\
1 \\
1 \\
1 \\
1 \\
1 \\
1 \\
1 \\
1 \\
1 \\
1\end{array}$ \\
\hline & $\begin{array}{l}\text { Anlayışlı } \\
\text { Mütevazi (tevazu, alçakgönüllü) } \\
\text { Empatik } \\
\text { Saygılı }\end{array}$ & $\begin{array}{l}4 \\
4 \\
4 \\
3\end{array}$ \\
\hline
\end{tabular}




\begin{tabular}{c|l|l}
\hline & Yardımsever & 2 \\
İnsani değer & Sevgi & 2 \\
boyutuyla hoşgörüu & Adil olmalı & 2 \\
& İyi bir dinleyici olmalı & 1 \\
& Sorumlu & 1 \\
& Duygulu & 1 \\
Dürüst & 1 \\
& Çalışkan & 1 \\
Önyargisız olmalı & 1 \\
& Katı kuralları olmayan & 1 \\
& Cesaret & 1 \\
& Barış & 1 \\
& Kardeşlik & 1 \\
& Sağduyu & 1 \\
& Cömert & 1 \\
& Güleryüzlü & 1 \\
& Samimi & 1 \\
& Sabırlı & 1 \\
& Sevecen & 1 \\
\hline Toplam & Taviz vermeli & 84 \\
\hline
\end{tabular}

2.3. Öğretmen adaylarına göre üniversite hayatının hoşgörülü olmaya katkısı var midır?

Öğretmen adayları genel olarak üniversite hayatının hoşgörülü olmaya katkı sağladığını düşünmektedir. Özellikle eğitim dersleri, grup çalışmaları, farklı insanlarla gerek yurtta gerekse fakültede birarada bulunmak hoşgörüye katkı sağlayan unsurlardır. Özellikle farklı insanlarla ve kültürlerle birarada bulunma ve iletişim kurma zorunluluğu bunun gelişmesinde etkili faktörlerdir.

SBÖ2 farklı düşünce ve yaşam tarzlarına sahip insanlarla birarada bulunulması dolayısıyla üniversite hayatının hoşgörülü olmaya katkı sağladığını “...Farklı düşünce ve yaşam tarzlar ile kendimden başka insanların da olduğunu ve onlarm hal ve hareketlerine saygılı olmayı ögretti" cümlesiyle ifade etmektedir. SÖ2 "Üniversite hayatının bu konuda katkısı çok fazla bence. Birçok farklı şehirden farklı kültürlere ait insanlar geliyor, davranış biçimleri farklı olyor ve bu bize göre yanlış bir davranış olabiliyor. Bu tarz durumlar daha sakin karşılanabiliyor." derken hoşgörü gösterilmesi gereken durumların neler olduğuna açıklık getirmektedir.

Üniversite hayatı, sosyal ilişkileri geliştirerek hoşgörülü olmaya katkı sağlamaktadır. MÖ1 "Üniversite hayatı sosyal ilişkilerin arttı̆̆ı bir dönem olduğu için 
hoşgörü kavramı hayatımızın başrolünde oluyor ister istemez..." cümlesiyle belirtmektedir.

Eğitim fakültesinde öğrenim görmek, mesleki derslerle ilişkilendirildiğinde hoşgörünün artmasına katkı sağlayıcı bir unsur olarak değerlendirilmektedir. $\mathrm{Bu}$ konuda OÖÖ3 “...Ĕ̆itim derslerinde gördüğümüz konular katkı sağladı..."derken MÖ1 “...Üniversitede aldı̆̆ımız eğitim dersleri de hoşgörülü bir öğretmen olmak açısından biz öğretmen adaylarına katkı să̆lamaktadır" şeklinde durumu ifade etmektedir.

Diğer taraftan birtakım olumsuzlukların hoşgörülü olmaya katkı sağladığı düşünülmektedir. SÖ3 "Yoktur, vardır. Yani hem yoktur hem de vardır. Burada bazı öğretmenler hoşgörüsüz, onlara bakıp hoşgörmeyi öğreniyoruz. Bazı insanlar, yurttaki öğrenciler de öyle. Onlara bakıp ne olup olmayacağımızı öğreniyoruz." cümlesiyle karşıt durumların hoşgörüye katkıda bulunabildiğine dikkat çekmektedir.

Aileden uzakta bulunmanın ve yalnız olmanın hoşgörülü olmayı mecbur hale getirdiğini belirten öğretmen adaylarından OÖÖ1 “...Sonuçta burada ailemizden uzak, kişiliklerine hakim tanıdık olmadığımız insanlara olaylara maruz kalıyoruz. Bazı durumlarda hoşgörülü olmak gerekiyor..." sözleriyle durumu ifade etmektedir.

Öğretmen adayları üniversite hayatının önyargıların kırılmasına ve hoşgörülü olmaya katkı sağladığını düşünmektedir. Bu konuda FBÖ2 “Kesinlikle var, insanlara olan önyargım kırıldı" cümlesiyle durumu belirtmektedir.

Tablo 4: Öğretmen Adaylarına Göre Üniversite Hayatının Hoşgörülü Olmaya Katkı Sağlayıp Sağlamadığı

\begin{tabular}{l|l|r}
\hline Tema & Kod & f \\
\hline \multirow{5}{*}{ Katkısı vardır } & İnsanlarla iletişim kurmayı (farklı İnsanlarla...) & 4 \\
Farklı olanı algılamaya(farklılıklara saygı, & 4 \\
& kültürler...) & 3 \\
& Eğitim dersleri (grup çalışmaları...) & 2 \\
& Hatayı görmeye ve tekrar yapmamaya (ders & 2 \\
& Olmaya) & 1 \\
& Önyargının kırılması & 1 \\
& Yaşanan sıkıntıların büyümemesine & 1 \\
& Herkesle konuşma imkanına sahip olmaya & 1 \\
& İnsanlara karşı anlayışlı olmaya & 1 \\
& Farklı insanlarla karşılaşmak & 1 \\
& İnsanlara karşı hoşgörülü olmaya & 1 \\
& Hayatımın her alanına katkı & 1 \\
& Sinirleri törpülemeyi öğretme & \\
\hline
\end{tabular}




\begin{tabular}{l|l|c}
\hline & Hoşgörüsüz öğretmenlerden hoşgörüyü & \\
& öğrenme & \\
\hline \multirow{3}{*}{ Katkısı yoktur } & Üniversitenin bir alakası yok, aile daha önemli & 2 \\
& bir faktör olduğu için & 1 \\
& Dersler ve KPSS ile uğraşmaktan & 1 \\
& Bence hiçbir katkısı yok & \\
\hline \multicolumn{2}{|l}{ Toplam } & 27
\end{tabular}

\section{Tartışma ve sonuç}

Çalışmada öğretmen adaylarından hoşgörüyü tanımlamaları, hoşgörülü bir öğretmenin hangi davranışlara sahip olması gerektiğini belirtmeleri ve üniversite hayatının hoşgörülü olmaya katkısının olup olmadığını ifade etmeleri istenmiştir. Böylece henüz mesleğe adım atmamış öğretmen adaylarının konuyu kendi ve mesleki açıdan ne şekilde değerlendirdikleri belirlenmeye çalışılmıştır. Zira nitelikli bir eğitimcinin hoşgörü sahibi olması beklenmektedir. Öğretmen adaylarından hoşgörüyle ilgili görüşlerinin alınması meslek öncesi hoşgörünün ne şekilde değerlendirildiğini ortaya koymak açısından önem taşıdığı gibi meslek öncesi ve sonrasındaki yaklaşımı analiz eden çalışmalara katkı sağlayacaktır. Çalışma hoşgörünün eğitimle olan ilişkisini belirlemenin yanısıra üniversite hayatının duruma katkı sağlayıcı noktalarının neler olduğunu ortaya çıkaracaktır.

Öğretmen adaylarının hoşgörüyü tanımlama biçimleri kavramın soyutluğuna vurgu yapar niteliktedir. Zira hoşgörü oldukça geniş bir biçimde kültürel, davranışsal ve duyuşsal değerlerle ifade edilmiştir. Hemşinli (2007:24)'e göre hoşgörü her ne kadar sözlük ve ansiklopedilerde karşılığı olan bir kavram olsa da tüm tanımlamaların aynı şeyi ifade ettiğini söylemek oldukça güçtür. Bir kavramın mahiyetini ortaya koymak ve onu çözüme kavuşturmak için aynı paydadaki kriterleride dikkate almak gerekmektedir. Özellikle soyut olan kavramların tanımlamalarını tam ve net olarak ortaya koymak ve bu tanımlar üzerinde bir ittifak sağlamak, somut kavramlara karşı daha zordur. Çünkü duygu ve düşünce ifade eden soyut kavramlar hakkında tanım yapmak duyu organlariyla algilanan somut kavramlara yapılan tanımlar kadar netlik ifade etmemektedir.

Hoşgörünün öğretmen adayları tarafından ifade edilme biçimleri arasında en fazla saygı değerinin vurgulandığı görülmektedir. Saygı değeri daha alt boyutlarda farklılıklara ve fikirlere saygı olarak da belirtilmiştir. Kavcara'a göre (1995) farklı olan duygu ve düşünceleri hoş karşılamak onları özgürce dile getirme olanağ1 tanımak hoşgörünün ön koşuludur. Bu anlamda öğretmen adaylarının hoşgörüyü saygıyı ifade eden tanımlamalarla kullanmaları belirtilen ön koşulun ifade edilebildiğini göstermektedir.

Çalışmada hoşgörü oldukça geniş bir boyutta tanımlanmıştır. Bu anlamda sevgisaygı, saygı ile yaklaşma, anlayışlı olma, empati kurma, hoşgörme ile 
nitelendirmeleri Büyükkaragöz (1995)'in hoşgörü ögeleri olarak belirttiği; “sevgi, saygı, güven, anlayış, kolaylaştırma, paylaşma, işbirliği, fonksiyonel hale getirme ve iletişim kurma" olgularının öğretmen adaylarında fikren mevcut olduğunu göstermektedir. Türe ve Ersoy (2014)'un sosyal bilgiler öğretmenleriyle gerçekleştirdikleri çalışmada hoşgörü; empati, saygılı olma, kabul etme şeklinde tanımlanmıştır. Karaman Kepenekçi (2004)'ün hoşgörü üzerine sınıf öğretmenleriyle yaptığı çalışmada da kavram benzer bir şekilde; "Anlayış", "Farklılıklara Saygı", "Sevgi", "Hata Payı Tanıma", "Affetme", "Önyargılı Olmama" ve "Uzlaşma" şeklinde ifade edilmiştir. Dolayısıyla kavram gerek öğretmenler gerekseöğretmen adayları tarfından benzer içerikle tanımlanmaktadır.

Tüm bu tanımlamalar hoşgörünün aynı zamanda bir değer olduğunu göstermektedir. Hoşgörüyle ilişkili değerler arasında sevgi, saygı, mutluluk, anlayış, empati, adalet, barış, demokrasi söz konusudur(Uca, 2015:27). Başaran (1995) hoşgörü ile ilgili sorunlardan birinin etkileşilen konuya insanın karşısındakinin açısından bakması olduğunu belirtmektedir. Öğretmen adaylarının hoşgörüyü empati kavramıyla tanımlamaları en azından bilişsel anlamda bunun kabul edildiğini göstermektedir.

Öğretmen adayları hoşgörüyü Mevlana gibi evrensel hoşgörü sahibi tarihi bir kişilikle tanımlanmanın yanısıra Türk'ün ayak bastığı yer ve Osmanlı olarak ifade ettikleri görülmektedir. Türklerin XI. yüzyıldan itibaren Anadolu coğrafyasını hakimiyetleri altına aldıklarında, daha önce Anadolu'da yaşamış olan toplulukların diline, dinine, geleneklerine ve bununla beraber bu toplulukların kültürüne ve kültür varlığı konumundaki tüm değerlerine saygılı davrandıkları bilinmektedir. Türk devlet felsefesi, kültüründen gelen hoşgörü anlayışı ile başka millet ve dinlere ait eserlere hiçbir zaman zarar verme anlayışına sahip olamamıştır. Özellikle Osmanlı Devleti üç kıtayı hâkimiyeti altına almasına rağmen, hiç bir bölgedeki kültür varlığını alıp başka yerlere taşımamış ya da o varlıkları yok etmemiştir (Göğebakan, 2010:212). Dolayısıyla öğretmen adayları açısından hoşgörünün tarihi ve milli bir değer olarak kabul edildiği anlaşılmaktadır.

Diğer taraftan hoşgörü müslümanlıkla ilişkili dini bir kavram olarak değerlendirilmektedir. Benzer yönede bir durum Gürkan'ın 1995 yılında üniversite öğrencileriyle yaptığı çalışmada Türkiye'de hoşgörü ortamının oluş nedenleri arasında "Türk milletinini manevi değerler gereği biribirine bağll, gelenek ve göreneklerin etkili olduğu ve dinin gereği" ifadeleri (1995: 72) dünden bugüne referans değerin etkisini korumaya devam ettiğini göstermektedir. Tüm bunlar hoşgörünün kültürel bir unsur olarak kabul edildiğinin bir ifadesidir.

Öğretmen adaylarına göre hoşgörü sahibi bir öğretmenin sevgi, sayg1, empati, yardımseverlik, sabırlı, adil, sorumlu özellikler taşıması gerekmektedir. Mutluer'in 7. sınıflarla yaptığı çalışmasında da değerlerin daha dar bir kapsamla ifade edilmesi 
hoşgörünün değer analmında yaşa bağlı olarak arttığını göstermektedir. Karaman Kepenekçi (2004)'ün sınıf öğretmenleriyle yaptığı benzer bir çalışmada hoşgörü, anlayış ve farklılıklara saygı olarak vurgulanmıştır.

Hoşgörüyü demokratik bir değer olarak ifade ederek yaşa bağlı olarak geliştiğini belirten çalışmalar bağlamında, üniversite hayatının hoşgörü oluşumuna katkı sağlıyor ve geliştiriyor olması bu yönde ileri sürülen görüşleri desteklemektedir. Karada $\breve{g}$ ve arkadaşları (2006) tarafından yapılan çalışmada 40 yaş üzeri öğretmenlerin demokratik değer algılayışlarının yaşa bağlı olarak gelişmesi, yaşın ve ortamın hoşgörüye etki eden unsurlar olduğunu göstermektedir.

Şahin (2011)'in öğretmen adayları ile gerçekleştirdiği çalışmasında hoşgörü eğitiminin asıl amacının yardım etmek olduğu bunun için öğretmenlerin öğrencilerinin öğrenmelerine yardımcı olacak startejileri geliştirmeleri gerektiği belirtilmektedir. Çalışmada öğretmen adaylarının hoşgörü sahibi bir öğretmenin öğrencisinin öğrenmesine katkıda bulunması ve bunun gereçekleşmesi için farklı yöntemler kullanması gerektiği ifadesi diğer arştırmanın sonuöçlarıyla örtüşmektedir. Dolayısyla öğretmenin öğretme düzeyi aynı zamanda hoşgörü düzeyinin göstergesi olarak kabul edilmektedir. Bu nokta öğretmenden hoşgörü anlamında beklenen sabrıda ifade eder niteliktedir.

Öğretmen adayları üniversite hayatının hoşgörü sahibi olmalarına katkı sağladığı düşüncesindedir. Bunun oluşumunda farklı kültürden insanların bir arada bulunması etkili bir faktör olarak belirtilmektedir. Bu sonuç Ersoy'un 2016 yılında dördüncü sınıf öğrencileriyle hoşgörü üzerine yaptı̆̆ı çalışmanın sonuçlarıyla örtüşmektedir. Öğretmenlere göre öğrencilerin çevrelerinde farklılıklara saygıya ilişkin sınırlı deneyim yaşamaları onların hoşgörü değerlerinin gelişiminde etkili bir faktördür. Dolayısıyla üniversite hayatında yaşanan deneyim hoşgörü sahibi olunmasına katkıda bulunmaktadır.

Karagöz ve Kesici (1996) tarafından sınıf öğretmenleri ile yapılan çalışmadan elde edilen sonuç demokrasinin olduğu yerde hoşgörünün kendiliğinden ortaya çıktığ1 yönündedir. $\mathrm{Bu}$ anlamda dolaylı düşünüldüğünde üniversitelerin hoşgörünün artamasında etkin rol oynayarak demokrasinin varlığına katkıda bulundukları söylenilebilir.

Bununla birlikte öğretmen adaylarının üniversitede hoşgörüyü ortaya çıkaran durumlar arasında aileden uzakta ve yalnız olmalarının başkalarına tahammül etme mecburiyetinde kalmalarına neden olduğunu belirtmeleri esasında hoşgörünün tanımına uymamaktadır. Bu anlamda öğretmen adaylarının bir kısmının hoşgörüyü doğru bir şekilde algılamadıkları, batıdan dilimize giren tolerans kavramını hoşgörü olarak nitelendirdikleri anlaşılmaktadır. Zira tolerans istenmeyen ancak zorunlu tahammül gösterilen durumlar için kullanılan bir kavramdır (Atalay, 2008:46). 
Öğretmen adayları fakültelerinde görmüş oldukları eğitimin ve özellikle meslek derslerinin hoşgörülü olmalarına katkıda bulunduğunu belirtmektedir. Van Yüzüncü Yıl Üniversitesi Eğitim Fakültesi'nde öğretmen adaylarına yönelik yapılan bir çalışmada eğitimin, hoşgörü eğilimlerinin artmasına katkı sağladığı tespit edilmiştir (Uca, 2015: 69). Bu anlamda öğretmen adayları benzer bir şekilde eğitimin hoşgörülü olmaya katkıda bulunduğu görüşündedir. Dolayısıyla pedogojik eğitim hoşgörü sahibi öğretmenlerin yetişmesinde temel unsurlar arasındadır.

Hoşgörü değerinin kazanılmasında üniversitenin etkide bulunmadığı yönünde beyan edilen görüşler bu noktada ailenin önemine vurgu yapmaktadır. Sağlam (2017)'e göre ailedeki değerler: saygı, sevgi, sabır, sadakat, sorumluluk ve hoşgörüdür. Dolayısıyla hoşgörü bir değer olarak çocukluk devresinde kazanılabilmektedir. Tüm bunlara karşın elde edilen veriler hoşgörünün bireyin eğitim süreci içerisinde yaşantı yoluyla geliştirilebilen bir kavram olduğunu ifade etmektedir.

\section{Kaynakça}

Arsoy, A. Figen (2016). “Dördüncü sınıf öğrencilerinin hoşgörü algısı ve deneyimleri: Bir fenomenolojik araştırma", Mersin Üniversitesi Eğitim Fakültesi Dergisi, 12(1), ss. 454-473.

Aslan, Ö. (2001). “Hoşgörü ve tolerans kavramlarına etimolojik açıdan analitik bir yaklaşım", Cumhuriyet Üniversitesi İlahiyat Fakültesi Dergisi, 5(2), 357-380.

Atalay Ölmez, Y. (2008). Felsefi açıdan tolerans ve hoşgörü, Basılmamış Yüksek Lisans Tezi Süleyman Demirel Üniversitesi Sosyal Bilimler Enstitüsü, Isparta.

Başaran, İ. E. (1995). Hoşgörü ve eğitim toplantısı açılış konuşması (Yayına haz: İ. Pehlivan), Ankara: UNESCO Türkiye Milli Komisyonu ve Ankara Üniversitesi Eğtim Bilimleri Fakültesi Ortak Yayın No: 2, ss. 47-55.

Bayındır, N. ve Özel, A. (2008). Gelişim ve öğrenme, Nisan Kitabevi: Ankara.

Beçene, Y. (2015). Anadolu'da hoşgörü kültürünün kaynaklarl, Basılmamış Yüksek Lisans Tezi Kahramanmaraş Sütçü İmam Üniversitesi Sosyal Bilimler Enstitüsü.

Boyacı, M., Ersever G. O. (2017). Hoşgörü eğilimi geliştirme programının 5. sınıf öğrencilerinin hoşgörü ve zorbalık düzeylerine etkisi, Eğitim ve Bilim, 42(189), ss. 167182.

Büyükkaragöz, S. ve Kesici, Ş. (1996). “Öğretmenlerin hoşgörü ve demokratik tutumları", Eğitim Yönetimi, 2 (3), ss: 353-365.

Göğebakan, Y. (2010). “Türk kültüründeki hoşgörü anlayışının tarihsel ve kültürel kaynakları ve bu anlayışın kültür varlıklarına yansımaları", İ.Ü. İlahiyat Fakültesi Dergisi, 1(2), ss. 201-223. 
Gündüz, M. (1995). Hoşgörü ve eğitim toplantısı açılış konuşması (Yayına haz: İ. Pehlivan), Ankara: UNESCO Türkiye Milli Komisyonu ve Ankara Üniversitesi Eğtim Bilimleri Fakültesi Ortak Yayın No: 2, ss. 13-15.

Gürkan, T. (1995). Hoşgörü ve eğitim toplantısı açılış konuşması (Yayına haz: İ. Pehlivan), Ankara: UNESCO Türkiye Milli Komisyonu ve Ankara Üniversitesi Eğtim Bilimleri Fakültesi Ortak Yayın No: 2, ss. 69-78.

Gürsoy, K. (1991). Felsefe ve hoşgörü, Felsefe Dünyası: Ankara.

Hemşinli, H. (2007). Din ve hoşgörü: İmkan ve sınırlılıklar, Basılamamış Yüksek Lisans Tezi, Yüzüncü Yıl Üniversitesi Sosyal Bilimler Enstitüsü, Van.

Karadağ, E., Baloğlu, N., ve Yalçınkayalar, P. (2006). "İlköğretim okul yöneticilerinin öğretmenler tarafından algılanan demokratik değerler üzerine ilişkisel bir araştırma", Değerler Eğitimi Dergisi, 4(12), ss. 65-82.

Karaman Kepenekçi, Y. (2004). "Sınıf öğretmenlerine göre hoşgörü", Kuram ve Uygulamada Eğitim Yönetimi, 38, ss: 250-265.

Kavcar, C. (1995). Hoşgörü ve eğitim toplantısı açılış konuşması (Yayına haz: İ. Pehlivan), Ankara: UNESCO Türkiye Milli Komisyonu ve Ankara Üniversitesi Eğtim Bilimleri Fakültesi Ortak Yayın No: 2, ss. 1-4.

Kaymakcan, R. (2007). Bir değer olarak hoşgörü ve eğitimi. R. Kaymakcan, S. Kenan, H. Hökelekli, Ş. Arslan ve M. Zengin (Ed), Değerler ve Eğitimi Uluslararası Sempozyumu İçinde (ss. 515-531), İstanbul: Dem.

Küçükbezirci, Y. (2013). "Mevlâna'nun hoşgörü felsefesi ve iletişim", Selçuk Üniversitesi Sosyal Bilimler Enstitüsü Dergisi, 30, ss. 19-25.

Mutluer, C. (2015). Sosyal bilgiler öğretmen adaylarının "hoşgörü" kavramına ilişkin metaforik algıları. Tarih Okulu Dergisi, 8(22), ss. 575-595.

Sağlam, İ. (2017). Bir değer ve eğitim merkezi olarak aile, Pegem Akademi: Ankara.

Sart, G. (2017). Nitel araştırma yöntem teknik analiz ve yaklaşım, Editörler: Fatma Nevra Seggie, Yasemin Bayyurt, Anı Yayıncılık: Ankara.

Şahin, Ç. (2011). "Perceptions of Prospective Teachers About Tolerance", Educational Research and Reviews, Vol. 6(1), pp. 77-86.

Uca, M. A. (2015). Eğitim fakültesi öğrencilerinin öğretmenlik mesleğine yönelik tutumları ile hoşgörü değerine sahip olma düzeyleri arasındaki ilişki, Basılmamış Yüksek Lisans Tezi, Yüzüncü Yıl Üniveristesi Eğitim Bilimleri Enstitüsü, Van.

Gürbüz, S. ve Şahin, F. (2016). Sosyal bilimlerde araştırma yöntemleri felsefe-yöntemanaliz, Seçkin Yayıncılık, Ankara. 